\title{
LETTER
}

\section{Clinical monitoring of peripheral perfusion: perspective on ProCess}

\author{
John PR Moore ${ }^{1,2^{*}}$ and John F Fraser ${ }^{2}$ \\ See related research by Lima and Bakker, http://ccforum.com/content/18/1/113
}

We read with interest the commentary by Lima and Bakker [1]. The authors note that there are two phases in the shock state that differ in the degree of uncoupling of macrocirculatory and microcirculatory function. They suggest that a shift to flow-based resuscitation may offer benefit for the critically ill by prioritising microcirculatory perfusion. This commentary is of particular interest when viewed in the context of ProCess [2], the recent negative early goal-directed therapy study.

The absence of a treatment effect in this trial from the therapies one would normally expect to resuscitate the microcirculation warrants consideration. Resuscitation attempts that reverse microcirculatory dysfunction early in the shock state appear to offer clinical benefit [3]. Conversely, in the phase of established shock the primary function of the microcirculation may be limiting damage by preventing spread of infection [4] and harmful excess oxygen delivery in parallel with mitochondrial shutdown and reduced oxygen consumption [5]. Microcirculatory dysfunction in established organ failure may therefore in fact be adaptive. Re-recruitment as a result of zealous resuscitation could hence be predicted to result in detrimental tissue effects. The ProCess trial utilised aggressive resuscitation strategies, without an endpoint that reflected microcirculatory perfusion in the context of ongoing metabolic need. This could be predicted to result in successful resuscitation of some patients and harm to others, dependent on their individual phase of illness.

We offer caution that despite the negative results from the ProCess trial, the concept of early goal-directed therapy should not yet be discounted, but should be revisited once valid clinical measures of microcirculatory and metabolic function are available.

\footnotetext{
* Correspondence: john.moore@health.qld.gov.au

'Department of Intensive Care, Nambour Hospital, Nambour, Queensland 4560, Australia

${ }^{2}$ Critical Care Research Group, The University of Queensland and The Prince

Charles Hospital, Brisbane, Queensland 4032, Australia
}

\section{Competing interests}

The authors declare that they have no competing interests.

Published: 30 October 2014

\section{References}

1. Lima A, Bakker J: Clinical monitoring of peripheral perfusion: there is more to learn. Crit Care 2014, 18:113.

2. ProCESS Investigators, Yealy DM, Kellum JA, Huang DT, Barnato AE, Weissfeld LA, Pike F, Terndrup T, Wang HE, Hou PC, LoVecchio F, Filbin MR, Shapiro NI, Angus DC: A randomized trial of protocol-based care for early septic shock. N Engl J Med 2014, 370:1683-1693.

3. Trzeciak S, McCoy JV, Phillip Dellinger R, Arnold RC, Rizzuto M, Abate NL, Shapiro NI, Parrillo JE, Hollenberg SM: Early increases in microcirculatory perfusion during protocol-directed resuscitation are associated with reduced multi-organ failure at $24 \mathrm{~h}$ in patients with sepsis. Intensive Care Med 2008, 34:2210-2217.

4. Melican K, Boekel J, Mansson LE, Sandoval RM, Tanner GA, Kallskog O, Palm F, Molitoris BA, Richter-Dahlfors A: Bacterial infection-mediated mucosal signalling induces local renal ischaemia as a defence against sepsis. Cell Microbiol 2008, 10:1987-1998.

5. Singer M, De Santis $V$, Vitale D, Jeffcoate W: Multiorgan failure is an adaptive, endocrine-mediated, metabolic response to overwhelming systemic inflammation. Lancet 2004, 364:545-548.

\section{doi:10.1186/s13054-014-0619-5}

Cite this article as: Moore and Fraser: Clinical monitoring of peripheral perfusion: perspective on ProCess. Critical Care 2014 18:619.

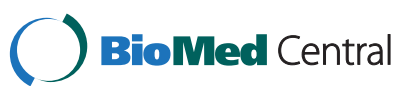

(c) 2014 Moore and Fraser; licensee BioMed Central Ltd. This is an Open Access article distributed under the terms of the Creative Commons Attribution License (http://creativecommons.org/licenses/by/4.0), which permits unrestricted use, distribution, and reproduction in any medium, provided the original work is properly credited. The Creative Commons Public Domain Dedication waiver (http://creativecommons.org/publicdomain/zero/1.0/) applies to the data made available in this article, unless otherwise stated. 